(c) American Dairy Science Association, 2006.

\title{
Milk Production of Dairy Cows Fed Differing Concentrations of Rumen-Degraded Protein ${ }^{1}$
}

\author{
K. F. Kalscheur, ${ }^{\star} \dagger^{2}$ R. L. Baldwin VI, $\dagger$ B. P. Glenn, $\dagger^{3}$ and R. A. Kohn ${ }^{\star 4}$ \\ *Department of Animal and Avian Sciences University of Maryland, College Park 20742 \\ †Bovine Functional Genomics Laboratory USDA-Agricultural Research Service, Beltsville, MD 20705
}

\begin{abstract}
Thirty-two multiparous and 16 primiparous Holstein cows in midlactation averaging $126 \mathrm{~d}$ in milk were used to determine the effects of rumen-degraded protein (RDP) concentration on lactation performance. Cows were assigned to diets in a repeated Latin square design with 3-wk experimental periods. Diets were formulated to provide 4 concentrations of dietary RDP [6.8, 8.2, 9.6 , and $11.0 \%$ of dry matter (DM)] while rumen-undegraded protein remained constant $(5.8 \%$ of DM). Diets contained 50\% corn silage and 50\% concentrate (DM basis). Ingredients within diets were equal across treatments except for ground corn, soybean meal, and ruminally protected soybean meal. Dry matter intake was not affected by treatment. Milk yield, fat yield, and protein yield all increased linearly when cows were fed diets with greater RDP. Milk fat and protein concentration each increased by 0.16 percentage units for cows fed $11 \%$ RDP compared with $6.8 \%$ RDP. Milk protein yield increased by $0.19 \mathrm{~g} / \mathrm{d}$ for every $1 \mathrm{~g} / \mathrm{d}$ increase in crude protein supplied mainly as RDP. As RDP increased, the efficiency of $\mathrm{N}$ use declined linearly. Milk urea $\mathrm{N}$ increased linearly when cows were fed increasing amounts of RDP, indicating increased losses of $\mathrm{N}$ via urine. Feeding deficient RDP diets to dairy cows can decrease nitrogen excretion, but it also decreases lactation performance. These data show an environmental benefit from underfeeding RDP to dairy cows according to National Research Council requirements, but at a financial cost to the dairy producer.
\end{abstract}

Key words: rumen-degraded protein, nitrogen efficiency, protein requirement, milk urea nitrogen

Received March 17, 2005.

Accepted September 2, 2005.

${ }^{1}$ Mention of a trade name or manufacturer does not constitute a guarantee or warranty of the product by the USDA or an endorsement over products not mentioned.

${ }^{2}$ Current address: Dairy Science Department, South Dakota State University, Brookings 57007.

${ }^{3}$ Current address: Biotechnology Industry Organization, 1225 I Street, NW, Ste 400, Washington, DC 20005-5958.

${ }^{4}$ Corresponding author: rkohn@umd.edu

\section{INTRODUCTION}

Over the past several decades, much of the research on determining protein requirements of high-producing dairy cows has focused on the amount and type of RUP in the diet. This research has established that during early lactation and before maximum DMI is reached, dairy cows need more protein than microbial synthesis in the rumen can provide to meet the requirements of high milk production (NRC, 2001). However, from the standpoint of AA profile and intestinal digestibility, microbial protein is often superior to most feed proteins (Clark et al., 1992). In their review of the literature, Clark et al. (1992) reported that microbial $\mathrm{N}$ supplied an average of 59\% of nonammonia $\mathrm{N}$ absorbed from the small intestine. The goal of feeding high-producing dairy cows is to optimize ruminal fermentation so that microbial growth is maximized. Diets should be balanced to provide sufficient $\mathrm{N}$ and energy to optimize microbial growth.

One of the first steps in diet formulation for lactating dairy cows is to provide sufficient RDP to meet the requirements of rumen microorganisms. The total metabolizable protein requirement of the cow is met by supplementing RUP when microbial protein synthesis alone is insufficient to meet the metabolizable protein requirements. Because excess protein in the ration of dairy cows is excreted, excess dietary protein may contribute to $\mathrm{N}$ pollution of the environment. Improving diet formulation to meet but not exceed the RDP requirement of microbes will optimize microbial growth, reduce $\mathrm{N}$ excretion, and improve overall $\mathrm{N}$ use by the cow.

The NRC (1989) requirements for RDP suggested $10.4 \% \mathrm{RDP}$ as the upper minimal dietary concentration required for microbial growth in high-producing cows. The most recent NRC publication (2001) ties RDP requirements to dietary energy intake where microbial $\mathrm{N}(\mathrm{g})$ is equivalent to $20.8 \times$ total digestible nutrients (TDN). Assuming the maximal efficiency of RDP use for microbial $\mathrm{N}$ synthesis is $85 \%$, the $\mathrm{RDP}$ requirement would be $24.5 \mathrm{~g}$ per g of TDN intake (NRC, 2001). Other research indicates that microbial synthesis may be improved when RDP is greater than $10.4 \%$ (Stokes et al., 
1991a,b); however, no previous research has evaluated the effect of feeding ruminally degraded protein in decreasing gradient levels. Feeding recommendations for RDP have been based on in vitro and in situ studies and theoretical calculations, and recommendations need to be tested in animal feeding experiments. Furthermore, the risk of economic loss due to decreased milk production from underfeeding RDP needs to be balanced against the potential for environmental damage due to overfeeding RDP. It is therefore necessary to determine how much milk production is likely to be lost from underfeeding RDP.

In research trials, often the ratio of RDP to RUP is changed while the CP content remains constant. Results from these experiments are difficult to interpret because the increasing concentration of RDP is confounded with the decreasing concentration of RUP. The effects of RDP deficiency can be masked by RUP excess. For example, reduced microbial protein from lack of RDP may not influence production if RUP substitutes for the microbial protein lost and more RUP allows for greater recycling of $\mathrm{N}$ back to the rumen. The current study was designed to test the effects of reducing RDP on ruminal fermentation and milk production, and therefore we intended to change only RDP concentration.

The objectives of this experiment were to: 1$)$ determine the effects of feeding RDP below predicted requirements on milk production, milk composition, DMI, feed efficiency, $\mathrm{N}$ use efficiency, and $\mathrm{N}$ excretion, 2) compare NRC (1989 and 2001) models with observed data from this experiment, and 3) quantify the cost in lost milk production from underfeeding RDP and compare that with the decreased feed cost. Results from this experiment will help determine optimal RDP concentrations of diets for lactating dairy cows to optimize milk production and milk components while reducing $\mathrm{N}$ excretion to the environment.

\section{MATERIALS AND METHODS}

\section{Cows, Treatments, and Management}

This study was conducted at the Central Maryland Research and Education Center under approval of the University of Maryland Animal Care and Use Committee. Thirty-two multiparous and 16 primiparous Holstein cows averaging $126(\mathrm{SD} \pm 53)$ DIM were blocked by parity ( 8 squares multiparous and 4 squares primiparous) and randomly assigned to dietary sequences within twelve $4 \times 4$ Latin squares. Before the start of the experiment, half of these cows (16 multiparous and 8 primiparous) had been managed separately, and were given treatments of bST (Posilac; Monsanto, St. Louis, $\mathrm{MO})$. These cows remained on bST throughout the ex- periment resulting in 6 bST-treated squares and 6 untreated squares. Latin squares were balanced for carryover effects to ensure that each treatment followed every other treatment one time within each square.

Each experimental period consisted of $21 \mathrm{~d}$ of which the first $14 \mathrm{~d}$ were for adaptation. Data from d 15 to 21 were used to compare treatment effects. Cows were housed in tie-stalls, milked twice daily at 0530 and 1730 $\mathrm{h}$, and fed once daily at $0800 \mathrm{~h}$. Cows treated with bST received injections on $\mathrm{d} 8$ of period 1 of the study and continued to receive bST every $14 \mathrm{~d}$. Therefore, cows received bST once during periods 1 and 3 (d 8), and twice during periods 2 and 4 (d 1 and 15). Because the design was a balanced $4 \times 4$ Latin square, an equal number of observations were made for each dietary treatment during periods in which bST was injected on d 8 vs. $d 1$ and 15. Two cows were removed from the study due to illness.

Diets were formulated to meet requirements for $\mathrm{NE}_{\mathrm{L}}$, RUP, minerals, and vitamins of a midlactation dairy cow (120 DIM) weighing $615 \mathrm{~kg}$, producing $41 \mathrm{~kg}$ of milk with $3.5 \%$ fat (NRC, 1989). Diets contained 50\% corn silage and 50\% concentrate (DM basis). Ingredients of the diets were equal across treatments except for changes in ground corn, solvent-extracted soybean meal, and nonenzymatically browned soybean meal (Soy Pass; Lignotech USA, Rothschild, WI). Ration formulation and composition are shown in Table 1 and ingredient composition is shown in Table 2. Diets provided 4 concentrations of dietary $\mathrm{RDP}(\%$ of $\mathrm{DM})$ while RUP was formulated to remain constant at $5.8 \%$ of DM: 1) $6.8 \% \mathrm{RDP}, 12.3 \% \mathrm{CP}$; 2) $8.2 \% \mathrm{RDP}, 13.9 \% \mathrm{CP}$ ); 3 ) 9.6\% RDP, $15.5 \% \mathrm{CP}$; and 4) $11.0 \% \mathrm{RDP}, 17.1 \% \mathrm{CP}$.

Estimates of protein degradability of the feed ingredients were from NRC (1989 and 2001), except for both soybean meal ingredients, which were determined in situ using a nylon bag technique (Erdman et al., 1987). Bags containing approximately $5 \mathrm{~g}$ of sample were placed in duplicate in the rumen of a late-lactation Holstein cow fed the 9.6\% RDP diet. Samples were removed from the rumen after $0,3,6,12,24$, and $36 \mathrm{~h}$. Bags were rinsed thoroughly, dried, and weighed. Crude protein disappearance data shown in Table 3 were fitted to a nonlinear model using the Marquardt iterative method as described previously by Erdman et al. (1987). Predicted CP degradation was calculated according to the NRC (2001) using feed analysis and estimated passage rates for the cows and rations in this study.

Each diet was evaluated for dietary $\mathrm{N}$ supply according to the NRC (1989 and 2001). The predicted protein requirement and supply for both models are presented in Table 4 . The lowest RDP diet was estimated to provide 69 or $68 \%$ of required RDP, and the 
Table 1. Ingredient and chemical composition of diets fed to dairy cows

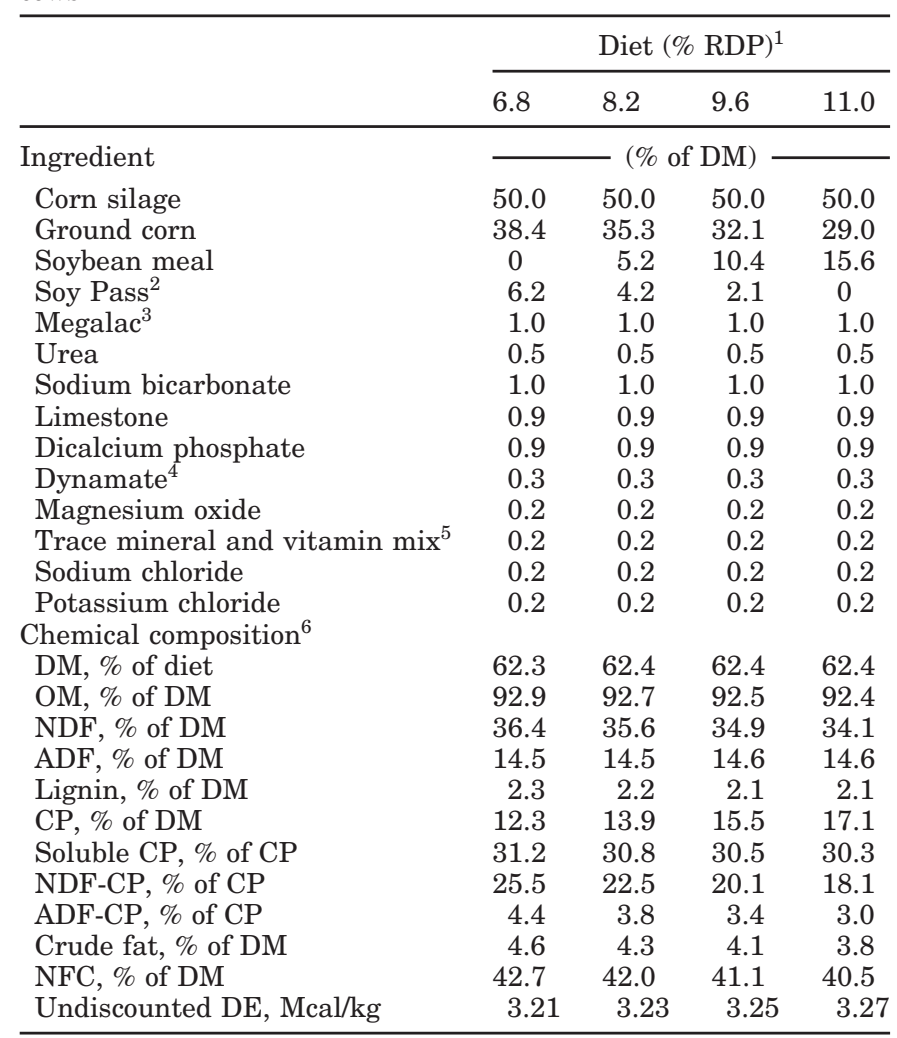

${ }^{1} \mathrm{RDP}$ (DM basis) according to NRC, 2001.

${ }^{2}$ Nonenzymatically browned soybean meal, Lignotech USA, Rothschild, WI.

${ }^{3}$ Church and Dwight Co., Princeton, NJ.

${ }^{4}$ IMC-Agrico Feed Ingredients (Bannockburn, IL); guaranteed analysis: $22 \% \mathrm{~S}, 18 \% \mathrm{~K}$, and $11 \% \mathrm{Mg}$.

${ }^{5}$ Formulated to provide (per kilogram of dietary DM) 6,600 IU of vitamin A, 1,540 IU of vitamin D, 22 IU of vitamin $\mathrm{E}, 50 \mathrm{mg}$ of $\mathrm{Mn}$, $50 \mathrm{mg}$ of $\mathrm{Zn}, 20 \mathrm{mg}$ of $\mathrm{Cu}, 0.6 \mathrm{mg}$ of I, $0.3 \mathrm{mg}$ of Se, and $0.1 \mathrm{mg}$ of Co.

${ }^{6} \mathrm{DM}, \mathrm{OM}, \mathrm{NDF}, \mathrm{ADF}$, lignin, $\mathrm{CP}$, soluble CP, NDF-CP, and ADF-CP are from analyzed feeds; crude fat, NFC, and undiscounted digestible energy (DE) are calculated from NRC (2001).

highest RDP diet was estimated to provide 114 and $111 \%$ of required RDP, according to the NRC 1989 and 2001 models, respectively. All diets were formulated to provide 98 or $127 \%$ of the RUP requirement for lactating cows for the NRC 1989 and 2001 models, respectively.

\section{Measurements and Analytical Procedures}

Milk production was recorded at each milking. Milk samples were collected during 4 consecutive milkings on d 19 and 20. Milk compositional analysis was conducted by Lancaster DHIA (Manheim, PA) according to approved procedures of AOAC (1990). Individual milk samples were analyzed for fat, total CP, lactose, SCC
Table 2. Composition of major ingredients used in diets

\begin{tabular}{|c|c|c|c|c|}
\hline Item & $\begin{array}{l}\text { Corn } \\
\text { silage }\end{array}$ & $\begin{array}{l}\text { Corn } \\
\text { grain }\end{array}$ & $\mathrm{SBM}^{1}$ & $\begin{array}{l}\text { Soy } \\
\text { Pass }^{2}\end{array}$ \\
\hline DM, \% of feed & 35.1 & 88.1 & 89.5 & 89.6 \\
\hline $\mathrm{OM}, \%$ of $\mathrm{DM}$ & 95.7 & 98.5 & 93.6 & 94.5 \\
\hline $\mathrm{NDF}, \%$ of $\mathrm{DM}$ & 53.6 & 20.0 & 9.5 & 31.3 \\
\hline $\mathrm{ADF}, \%$ of $\mathrm{DM}$ & 26.5 & 2.0 & 5.0 & 7.5 \\
\hline Lignin, \% of DM & 3.5 & 0.8 & 0.7 & 3.2 \\
\hline $\mathrm{CP}, \%$ of $\mathrm{DM}$ & 8.6 & 8.6 & 56.8 & 53.2 \\
\hline Soluble CP, \% of CP & 56.2 & 1.7 & 19.2 & 6.6 \\
\hline NDF-CP, \% of CP & 22.0 & 26.2 & 2.1 & 39.7 \\
\hline $\mathrm{ADF}-\mathrm{CP}, \%$ of $\mathrm{CP}$ & 6.5 & 2.0 & 2.0 & 6.1 \\
\hline RUP (NRC, 1989$)^{3} \%$ of CP & 31 & 52 & 40 & - \\
\hline RUP (NRC, 2001$)^{4} \%$ of CP & 35.1 & 46.6 & 41.8 & 77.2 \\
\hline
\end{tabular}

${ }^{1} \mathrm{SBM}=$ Soybean meal.

${ }^{2}$ Nonenzymatically browned soybean meal, Lignotech USA, Rothschild, WI.

${ }^{3}$ Tabular values from NRC, 1989.

${ }^{4}$ Calculated using tabular values for feed composition and estimated passage rates $(0.071 / \mathrm{h}$ for grains; $0.054 \mathrm{~h}$ for silage $)$ from NRC, 2001.

(Bentley 2500 Combi, Chaska, MN), and MUN (Bentley ChemSpec 150); and 4\% FCM (kg/d) was calculated $(\mathrm{NRC}, 2001)$ as $0.4 \times$ milk yield $(\mathrm{kg} / \mathrm{d})+15 \times$ fat yield $(\mathrm{kg} / \mathrm{d})$. Body weights were recorded weekly. The DM percentage of corn silage was determined weekly, and diets were adjusted accordingly to ensure constant forage-to-concentrate ratio on a DM basis. Individual feed intakes and refusals were recorded daily. Cows were fed ad libitum by targeting $10 \%$ refusals. Daily samples of corn silage, corn, and concentrate mixes fed during the last week of each experimental period were composited, oven-dried at $60^{\circ} \mathrm{C}$, and ground through a Wiley mill (1-mm screen; Arthur H. Thomas, Philadelphia, PA). Composited samples of corn silage, corn, and concentrates were analyzed for $\mathrm{DM}\left(100^{\circ} \mathrm{C}\right.$ overnight $)$, ash $\left(500^{\circ} \mathrm{C}\right.$ overnight), sequential $\mathrm{NDF}, \mathrm{ADF}$, and lignin (Mertens, 2002). Total N was determined by micro-Kjeldahl digestion with automated procedures (Technicon method no. 334-74; Technicon Instruments Corp., Tar-

Table 3. Ruminal CP degradation in situ data for soybean meal ingredients

\begin{tabular}{lcc}
\hline & \multicolumn{2}{c}{$\begin{array}{c}\text { Soybean meal } \\
\text { ingredients }\end{array}$} \\
\cline { 2 - 3 } Protein fraction, \% of CP & $\mathrm{SBM}$ & Soy Pass \\
\hline A (soluble fraction) & 13.2 & 0 \\
B (slowly degraded) & 86.8 & 95.1 \\
C (undegraded) & 0 & 4.9 \\
Degradation rate, \%/hr & 9.15 & 2.8 \\
RUP, in situ (NRC, 2001) & 37.9 & 73.1 \\
\hline
\end{tabular}

${ }^{1} \mathrm{SBM}=$ Solvent-extracted soybean meal ; Soy Pass = nonenzymatically browned soybean meal, Lignotech USA, Rothschild, WI.

${ }^{2}$ Calculated using in situ degradation data and passage rate $(0.071 /$ h) determined by NRC, 2001 for intended cows and ration. 
Table 4. Calculated RDP, RUP, absorbed protein (AP), and MP according to the NRC 1989 and 2001 models

\begin{tabular}{|c|c|c|c|c|}
\hline \multirow[b]{2}{*}{ Estimates $^{1}$} & \multicolumn{4}{|c|}{$\operatorname{Diet}(\% \mathrm{RDP})^{2}$} \\
\hline & 6.8 & 8.2 & 9.6 & 11.0 \\
\hline \multicolumn{5}{|l|}{ NRC 1989 model } \\
\hline RDP supplied (\% of DM) & 6.8 & 8.2 & 9.7 & 11.2 \\
\hline RUP supplied (\% of DM) & 5.5 & 5.7 & 5.8 & 5.9 \\
\hline AP supplied (\% of DM) & 9.5 & 10.4 & 11.4 & 11.7 \\
\hline RDP required (\% of DM) & 9.8 & 9.8 & 9.8 & 9.8 \\
\hline RUP required (\% of DM) & 5.8 & 5.8 & 5.9 & 5.8 \\
\hline AP required $(\% \text { of } \mathrm{DM})^{3}$ & 11.7 & 11.7 & 11.7 & 11.7 \\
\hline RDP supplied (\% of required) & 69.3 & 84.3 & 99.2 & 114.2 \\
\hline RUP supplied (\% of req & 94.6 & 97.0 & 98.9 & 101.0 \\
\hline AP supplied (\% of required $)^{3}$ & 81.2 & 89.5 & 97.4 & 100.4 \\
\hline Allowable milk, kg/d & 24.7 & 28.7 & 32.5 & 34.0 \\
\hline \multicolumn{5}{|l|}{ NRC 2001 model } \\
\hline RDP supplied (\% of DM) & 6.8 & 8.2 & 9.6 & 11.0 \\
\hline RUP supplied (\% of DM) & 5.5 & 5.7 & 5.9 & 6.1 \\
\hline MP supplied (\% of DM) & 8.9 & 9.9 & 10.8 & 11.1 \\
\hline RDP required (\% of DM) & 9.9 & 9.9 & 9.9 & 9.9 \\
\hline RUP required (\% of DM) ${ }^{4}$ & 4.6 & 4.6 & 4.6 & 4.6 \\
\hline MP required $(\% \text { of } \mathrm{DM})^{5}$ & 10.0 & 9.9 & 9.8 & 9.8 \\
\hline RDP supplied (\% of required) & 68.4 & 82.5 & 96.7 & 110.9 \\
\hline RUP supplied (\% of required $)^{4}$ & 120.5 & 125.4 & 129.7 & 133.6 \\
\hline MP supplied (\% of required $)^{5}$ & 88.7 & 99.3 & 109.6 & 113.6 \\
\hline Allowable milk, kg/d & 27.7 & 33.4 & 38.9 & 40.9 \\
\hline
\end{tabular}

${ }^{1}$ All estimates assume feed composition as measured, and predicted DMI for milk production of 11.0 RDP diet. Tabular values were used for RUP, except in situ ruminal CP degradation values were used for soybean meals.

${ }^{2} \mathrm{RDP}$ (DM basis) according to NRC, 2001.

${ }^{3} \mathrm{AP}=$ Absorbed protein as calculated by NRC (1989) except microbial CP estimated as a fraction of RDP when diets were deficient in RDP based on NRC (1989) text. Microbial CP, g/d $=0.9 \times(\mathrm{RDP}+$ $0.15 \mathrm{CP}$ intake).

${ }^{4} \mathrm{RUP}$ requirement calculated with assumption of adequate RDP (i.e., RUP requirement does not compensate for estimated reduction in microbial protein due to inadequate RDP).

${ }^{5} \mathrm{MP}=$ Metabolizable protein as calculated by NRC (2001).

rytown, NY) and NDF-CP, ADF-CP, and soluble $\mathrm{CP}$ were determined by methods described by Licitra et al. (1996). Predicted urinary and fecal $\mathrm{N}$ outputs were calculated according to Jonker et al. (1998).

\section{Data Analysis}

Prior to the start of the experiment, treatments were randomly assigned to cows blocked into squares by parity and management. Because the row effect of the Latin square was period and was shared by all squares, the experiment was statistically analyzed as a Latin rectangle (Mead et al., 1993). Data were analyzed using the mixed model procedure of SAS (SAS Institute, 1996). The statistical model was $\mathrm{Y}=$ treatment + parity + management $+($ treatment $\times$ parity $)+($ treatment $\times$ management $)+($ parity $\times$ management $)+($ treatment $x$ parity $\times$ management $)+$ period + cow (parity, management). The random effect was cow nested within parity and management. Interactions were not significant and were dropped from the model in a stepwise manner. Effects from the pattern of bST injections are part of the period effect. Unless noted in the tables and text, the management effect, which includes the effect of bST injections, was not significant. When the treatment effect was significant $(P<0.10)$, treatment least squares means were separated using the PDIFF test (SAS Institute, 1996) where $P<0.05$, and orthogonal polynomials were used to test linear (weighted $3,1,-1,-3$ ), quadratic (weighted $1,-1,-1,1$ ), and cubic responses (weighted $-1,3,-3,1)$ of increasing concentrations of RDP in the diet (Gill, 1978). Cubic responses were not significant $(P>0.1)$, and therefore were not included in the tables or text.

In practice, diet formulation requires the prediction of both DMI and the requirement and supply of nutrients so that target feed nutrient concentrations can be determined. Our evaluation of the NRC models (1989 and 2001) separated the DMI prediction from that of protein requirement and supply. The predicted DMI was determined for each individual cow using the observed milk production. Then, the protein requirement, supply and amount of milk (allowable milk) that could be produced by this amount of protein were determined using the individually measured DMI. Both of these predictions were evaluated against the measured DMI or milk production. The average difference in prediction vs. observed was taken as the mean bias. The root mean square prediction error (RMSPE) was calculated as: $\left.\sqrt{ }\left\{\Sigma[\text { (predicted - observed })^{2}\right] / \mathrm{n}\right\}$ (Bibby and Toutenburg, 1977). Residuals (predicted - observed) were plotted against predicted values of DMI to identify slope biases. Residuals were plotted against observed values of milk production because allowable-milk predictions were made by reversing the equations developed by regression within the NRC models. Therefore, although it is customary to plot residuals vs. predicted values to avoid detection of unmeaningful slope bias, the opposite is true when the equations have been reversed (Kohn et al., 1998). The residuals for allowable milk were plotted against observed milk minus the milk production for the high RDP diet (control). The control milk was predicted for individuals fed lower RDP diets by using the prediction coefficients for the cow and period of those individuals and the coefficient for the control diet.

An economic analysis was conducted to compare the increased cost of feed for higher RDP diets to the additional value of milk components produced on those diets. Five-year average prices (2000 to 2004) were used for soybean meal $(\$ 0.22 / \mathrm{kg})$, corn grain $(\$ 0.097 / \mathrm{kg})$, and milk $(\$ 0.28 / \mathrm{kg})$. Grain prices were obtained indirectly from the Chicago Board of Trade from Capitol Commodity Services, Inc. (2005). Soy Pass was estimated to 
Table 5. Least squares means for intake, milk yield, milk composition, and body weight of dairy cows fed increasing concentrations of RDP and for 2 levels of parity

\begin{tabular}{|c|c|c|c|c|c|c|c|c|c|}
\hline & \multicolumn{4}{|c|}{$\operatorname{Diet}(\% \mathrm{RDP})^{1}$} & SEM & Treatment & Parity & \multicolumn{2}{|c|}{ Contrast } \\
\hline \multicolumn{10}{|l|}{ Intake } \\
\hline $\mathrm{CP}, \mathrm{kg} / \mathrm{d}$ & $2.51^{\mathrm{d}}$ & $2.92^{\mathrm{c}}$ & $3.29^{\mathrm{b}}$ & $3.65^{\mathrm{a}}$ & 0.06 & $<0.001$ & 0.06 & $<0.001$ & 0.57 \\
\hline $\mathrm{RDP}, \mathrm{kg} / \mathrm{d}^{2}$ & $1.41^{\mathrm{d}}$ & $1.74^{\mathrm{c}}$ & $2.06^{\mathrm{b}}$ & $2.38^{\mathrm{a}}$ & 0.03 & $<0.001$ & 0.03 & $<0.001$ & 0.75 \\
\hline RUP, kg/d ${ }^{2}$ & $1.10^{\mathrm{c}}$ & $1.18^{\mathrm{b}}$ & $1.23^{\mathrm{ab}}$ & $1.28^{\mathrm{a}}$ & 0.03 & $<0.001$ & 0.14 & $<0.001$ & 0.42 \\
\hline $\mathrm{NE}_{\mathrm{L}}, \mathrm{Mcal} / \mathrm{d}^{2}$ & $32.6^{\mathrm{b}}$ & $33.5^{\mathrm{ab}}$ & $34.0^{\mathrm{a}}$ & $34.5^{\mathrm{a}}$ & 0.57 & 0.01 & 0.05 & 0.001 & 0.58 \\
\hline $4.0 \% \mathrm{FCM}, \mathrm{kg} / \mathrm{d}$ & $30.3^{\mathrm{c}}$ & $30.8^{\mathrm{bc}}$ & $32.2^{\mathrm{ab}}$ & $33.1^{\mathrm{a}}$ & 0.78 & 0.02 & 0.08 & $<0.001$ & 0.97 \\
\hline Milk fat, \% & $3.70^{\mathrm{b}}$ & $3.74^{\mathrm{ab}}$ & $3.82^{\mathrm{ab}}$ & $3.86^{\mathrm{a}}$ & 0.07 & 0.07 & 0.49 & 0.009 & 0.90 \\
\hline Milk fat yield, $\mathrm{kg} / \mathrm{d}$ & $1.17^{\mathrm{c}}$ & $1.20^{\mathrm{bc}}$ & $1.26^{\mathrm{ab}}$ & $1.30^{\mathrm{a}}$ & 0.04 & 0.02 & 0.11 & 0.001 & 0.97 \\
\hline Milk CP, $\%^{3}$ & $2.95^{\mathrm{c}}$ & $3.06^{\mathrm{b}}$ & $3.09^{\mathrm{ab}}$ & $3.11^{\mathrm{a}}$ & 0.03 & $<0.001$ & 0.83 & $<0.001$ & 0.03 \\
\hline Milk CP yield, kg/d & $0.94^{\mathrm{c}}$ & $0.98^{\mathrm{b}}$ & $1.02^{\mathrm{ab}}$ & $1.05^{\mathrm{a}}$ & 0.03 & $<0.001$ & 0.14 & $<0.001$ & 0.66 \\
\hline Milk lactose, \% & 4.78 & 4.76 & 4.78 & 4.77 & 0.03 & 0.79 & 0.78 & - & - \\
\hline Milk lactose yield, $\mathrm{kg} / \mathrm{d}$ & $1.52^{\mathrm{b}}$ & $1.52^{\mathrm{b}}$ & $1.58^{\mathrm{ab}}$ & $1.61^{\mathrm{a}}$ & 0.04 & 0.02 & 0.10 & $<0.001$ & 0.73 \\
\hline
\end{tabular}

${ }^{\mathrm{a}-\mathrm{d}}$ Means within row with unlike superscripts differ $(P<0.05)$.

${ }^{1} \mathrm{RDP}$ (DM basis) according to NRC (2001).

${ }^{2}$ Determined using NRC (2001) with analyzed feeds and observed DMI.

${ }^{3}$ Management group effect (cows from a group that received bST vs. a group that did not receive bST; $P<0.05$ ).

${ }^{4}$ Feed efficiency $(\%)=4.0 \% \mathrm{FCM}(\mathrm{kg} / \mathrm{d}) / \mathrm{DMI}(\mathrm{kg} / \mathrm{d})$.

be $\$ 0.03 / \mathrm{kg}$ higher than that of soybean meal. Milk component prices were calculated as the average price for Class II components published by the USDA (2005). Five-year average price of milk fat was $\$ 3.33 / \mathrm{kg}$, protein was $\$ 4.68 / \mathrm{kg}$, and price of other solids was $\$ 0.15 / \mathrm{kg}$.

\section{RESULTS AND DISCUSSION}

As shown in Table 4, both NRC models (1989 and 2001) predicted similar deficiencies, and RDP concentrations ranged from 68 to $111 \%$ of NRC (2001) requirements. Both models also predicted RUP concentrations to be similar across treatments, but the NRC 1989 model predicted RUP to average $98 \%$ of requirement whereas the 2001 model predicted RUP to average $127 \%$ of requirement. Both models predicted similar RUP supply, but NRC 2001 predicted a lower RUP requirement. Thus, NRC 2001 did not predict the 9.6 or $11.0 \%$ RDP diets to be deficient in metabolizable protein but NRC 1989 predicted the 9.6\% RDP diet to be slightly deficient and the higher RDP diet was predicted to be adequate in total protein. The NRC 1989 model predicted greater losses in milk production for the deficient diets.

Dry matter intake was not affected by dietary RDP concentration (Table 5), but multiparous cows consumed more than primiparous cows (21.7 vs. $20.5 \mathrm{~kg} /$ $\mathrm{d} ; P<0.05)$. When nutrients like protein are provided in insufficient quantities for microbial fermentation, rate of digestion and DMI can be reduced (Faverdin, 1999). In corn silage-based diets, cows fed increasing levels of protein and RDP, provided by soybean meal or urea, resulted in greater DMI in some studies (Wohlt and Clark, 1978; M'hamed et al., 2001), but not others (Armentano et al., 1993). In the present study, feed intake may not have been limited by rumen bulk because of the high-energy diet, and therefore, potentially reduced microbial fermentation from low RDP diets may not have affected intake (Allen, 1999). In agreement with treatment formulation, intake of RDP increased from 1.41 to $2.38 \mathrm{~kg} / \mathrm{d}$ for the lowest to the highest RDP diets. Intake of RUP and $\mathrm{NE}_{\mathrm{L}}$ also increased slightly as DMI increased nonsignificantly with increasing RDP.

Milk production increased as RDP increased in the diet (Table 5). Cows fed the lowest RDP diet produced $2.1 \mathrm{~kg} / \mathrm{d}$ less milk than cows fed the highest RDP diet indicating that RDP was deficient in the low RDP diet. Although differences in milk production were not significant between any diet and the next closest treatment, the linear trend extended to the full range of the treatments. The primary evidence for feeding dietary $\mathrm{RDP}$ at concentrations greater than $9.5 \%$ is from in vitro continuous culture experiments (Stokes et al., 1991b). As long as carbohydrates were not limiting, bacterial $\mathrm{N}$ and bacterial efficiency continued to increase as RDP increased in the diets (Stokes et al., 1991b). In a metabolism study, cows fed diets formu- 


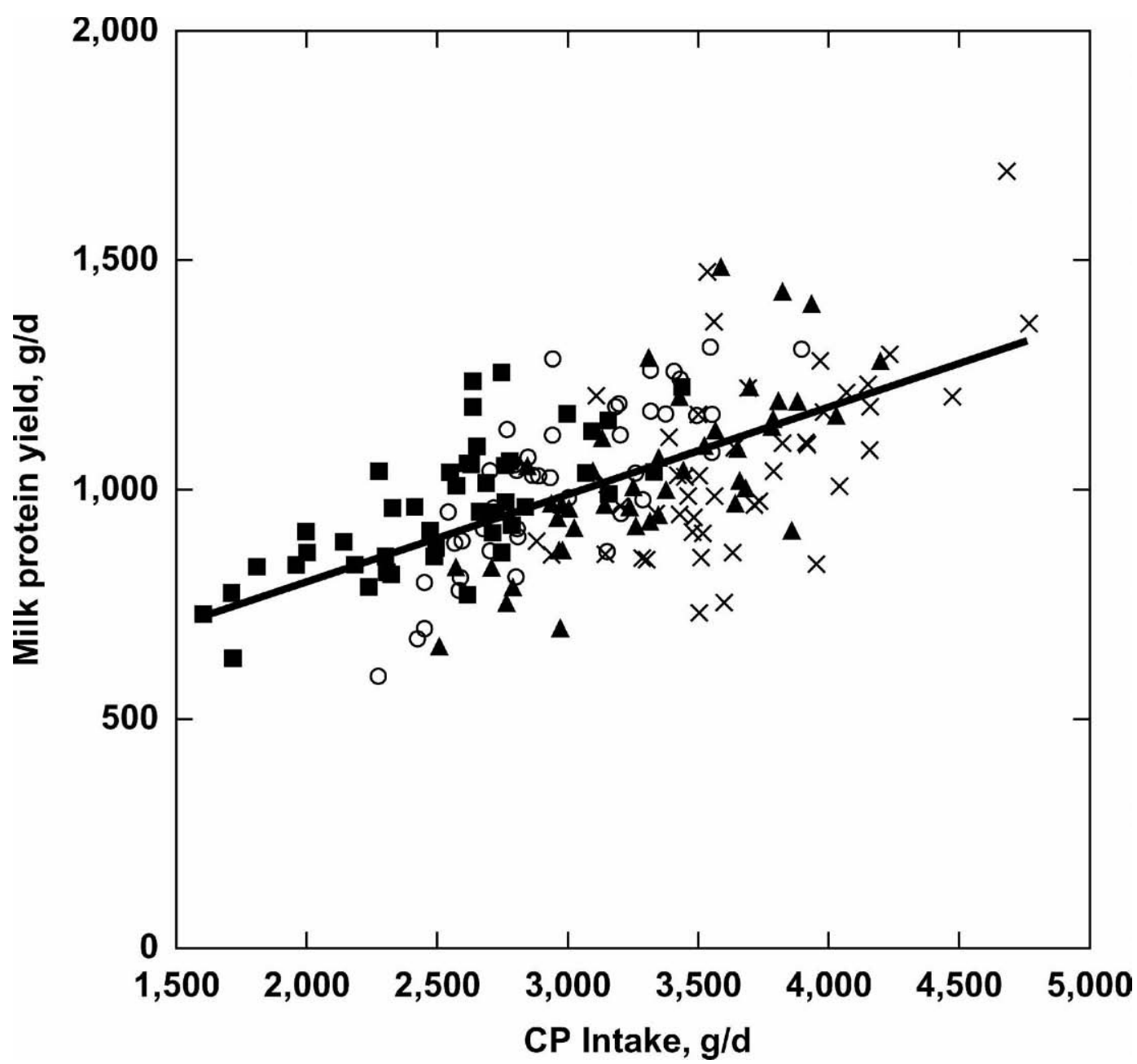

Figure 1. Effect of CP intake (g/d) on milk protein yield (g/d) for cows fed diet RDP concentrations of $6.8(\mathbb{\square}), 8.2(\bigcirc), 9.6(\mathbf{\Delta})$, and 11.0 $(\times) \%$ of DM. The equation is $\mathrm{Y}($ milk protein, $\mathrm{g} / \mathrm{d})=425(\mathrm{SE}=55)+0.19(\mathrm{SE}=0.018) \times(\mathrm{CP}, \mathrm{g} / \mathrm{d})$ with $\mathrm{R}^{2}=0.39$.

lated to contain 11.8 or $13.7 \%$ RDP supported greater microbial protein synthesis than diets containing $9 \%$ RDP (Stokes et al., 1991a), lending support to the theory that greater RDP will support greater microbial protein synthesis and consequently, greater milk production. However, in a production study with lactating dairy cows (Armentano et al., 1993), increasing RDP from 9.5 to $11.7 \%$ RDP did not result in increased milk production, indicating that there was no benefit to feeding diets with RDP greater than 9.5\%. In the present production study, milk production was highest for cows fed the highest RDP diets, but the study was not designed to determine if even greater milk production could have been obtained from feeding even more RDP.

Fat-corrected (4.0\%) milk improved from 30.3 to 33.1 $\mathrm{kg} / \mathrm{d}$ as RDP increased in the diets. Cows fed the lowest RDP diet produced less FCM than cows fed the 2 higher RDP diets $(P<0.05)$. Cows fed to meet RDP require- ments produced the greatest concentrations and yields of milk fat. Fat percentage was $3.70 \%$ for cows fed the lowest RDP diets and increased linearly to $3.86 \%$ as RDP increased in the diets $(P<0.01)$. This observation supports research which demonstrated that providing additional RDP increases fat percentage and yield (M'hamed et al., 2001), although others have not observed fat percentage or yield differences when dietary RDP was increased (Armentano et al., 1993). In a summary of previous literature, the NRC (2001) reported higher milk fat percentage with improved methionine and lysine nutrition; however, results were variable. Methionine and lysine may play a role in milk fat synthesis through increased de novo synthesis of shortand medium-chain fatty acids or through increased synthesis of chylomicrons and very low-density lipoproteins (NRC, 2001); however, limited data are available. In the current study, increased AA absorbed from the 
Table 6. Nitrogen balance of cows fed diets increasing in RDP

\begin{tabular}{|c|c|c|c|c|c|c|c|c|c|}
\hline & \multicolumn{4}{|c|}{$\operatorname{Diet}(\% \mathrm{RDP})^{1}$} & \multirow[b]{2}{*}{ SEM } & \multirow[b]{2}{*}{ Treatment } & \multirow[b]{2}{*}{ Parity } & \multicolumn{2}{|c|}{ Contrast } \\
\hline & 6.8 & 8.2 & 9.6 & 11.0 & & & & Linear & Quadratic \\
\hline Intake $\mathrm{N}, \mathrm{g} / \mathrm{d}$ & $403^{\mathrm{d}}$ & $467^{\mathrm{c}}$ & $526^{\mathrm{b}}$ & $586^{\mathrm{a}}$ & 3.4 & $<0.001$ & 0.09 & $<0.001$ & 0.94 \\
\hline Milk N, g/d & $147^{\mathrm{c}}$ & $153^{\mathrm{b}}$ & $160^{\mathrm{ab}}$ & $165^{\mathrm{a}}$ & 4.7 & $<0.001$ & 0.14 & $<0.001$ & 0.66 \\
\hline Urine $\mathrm{N}^{2,3} \mathrm{~g} / \mathrm{d}$ & $119^{\mathrm{d}}$ & $146^{\mathrm{c}}$ & $177^{\mathrm{b}}$ & $205^{\mathrm{a}}$ & 3.8 & $<0.001$ & 0.42 & $<0.001$ & 0.79 \\
\hline Fecal N, ${ }^{3,4} \mathrm{~g} / \mathrm{d}$ & $137^{\mathrm{d}}$ & $168^{\mathrm{c}}$ & $189^{\mathrm{b}}$ & $216^{\mathrm{a}}$ & 8.4 & $<0.001$ & 0.27 & $<0.001$ & 0.56 \\
\hline $\mathrm{N}$ efficiency, $5 \%$ & $36.5^{\mathrm{d}}$ & $32.8^{\mathrm{c}}$ & $30.4^{\mathrm{b}}$ & $28.2^{\mathrm{a}}$ & 0.5 & $<0.001$ & 0.82 & $<0.001$ & 0.01 \\
\hline \multirow{2}{*}{\multicolumn{10}{|c|}{${ }^{\mathrm{a}-\mathrm{d}}$ Means in the same row with unlike superscripts differ $(P<0.05)$. }} \\
\hline & & & & & & & & & \\
\hline \multicolumn{10}{|c|}{${ }^{2}$ Predicted urine N output; $12.54 \times$ MUN (Jonker et al., 1998). } \\
\hline \multicolumn{10}{|c|}{${ }^{3}$ Management effect (cows received bST vs. cows that did not receive bST; $P<0.05$ ). } \\
\hline \multicolumn{10}{|c|}{$\begin{array}{l}{ }^{4} \text { Predicted fecal } N+\text { retained } N(\text { assumed equal to } 0)=N \text { intake }- \text { predicted urinary } N-\text { milk } N \text {. } \\
{ }^{5} \mathrm{~N} \text { efficiency }(\%)=100 \times \text { Milk } N(\mathrm{~g} / \mathrm{d}) / \text { Intake } N(\mathrm{~g} / \mathrm{d}) .\end{array}$} \\
\hline
\end{tabular}

small intestine may have increased the supply of precursors available to increase milk fat percentage for cows fed increasing concentrations of RDP.

Increasing RDP from 6.8 to $11.0 \%$ in the diets of lactating cows increased milk CP concentration from 2.95 to $3.11 \%$ and protein yield from 0.94 to $1.05 \mathrm{~kg} / \mathrm{d}$ (Table 5). Cows fed to meet RDP requirements produced the greatest amount of protein in milk. Cows fed the lowest RDP produced milk with a lower protein percentage than cows fed the other diets $(P<0.001)$. The relationship between CP supplied in the diet, mainly as $\mathrm{RDP}$, and milk protein production is illustrated in Figure 1. Increased milk protein percentage and milk protein production in response to increasing RDP in the diet may be a result of providing additional $\mathrm{N}$ for ruminal microbial protein synthesis.

The slope of the line (0.19) in Figure 1 indicates that $19 \%$ of CP added to the diet was eventually converted to milk CP. The NRC (2001) estimates that when RDP is limiting to microbial growth, $85 \%$ of RDP can be converted to microbial CP. This microbial CP is $64 \%$ metabolizable, and the metabolizable $\mathrm{CP}$ is used for lactation at $67 \%$ efficiency after accounting for maintenance, lactation, and growth. These coefficients factor together to $36 \%$. The previous NRC (1989) calculations assumed $90 \%$ efficiency of RDP use for microbial growth, plus $15 \%$ of $\mathrm{CP}$ intake recycled to the rumen, $64 \%$ digestibility of bacterial $\mathrm{CP}$, and $70 \%$ efficiency of use of absorbed protein for lactation. These coefficients factor together to an assumed efficiency of conversion of $47 \%$. Both estimates are greater than $19 \%$ observed in this study; however, our slope may be skewed because some cows may have been fed RDP in excess of requirements. When we excluded the data from the highest RDP diet, the slope was unaffected (0.22; SE = 0.021), suggesting a linear response to RDP deficiency at a lower magnitude than predicted by the NRC 1989 and 2001 models.
Multiparous cows produced $1.8 \mathrm{~kg} / \mathrm{d}$ more milk than primiparous cows $(P<0.08)$, but there was no parity by treatment interaction, indicating that the RDP requirements for primiparous and multiparous cows are similar once feed intake and animal performance are taken into account. Primiparous and multiparous cows were not significantly different in fat percentage, fat yield, protein percentage, protein yield, lactose percentage, or lactose yield.

Body weight did not differ by dietary treatment group (Table 5). Multiparous cows weighed more than primiparous cows in this study (607 vs. $562 \mathrm{~kg} ; P<0.01$ ). There was a treatment by lactation interaction $(P<$ 0.001) for BCS (data not shown); for primiparous cows, BCS declined as RDP increased in the diet (3.37, 3.27, 3.16 , and 3.14 for cows fed the 4 diets in order of increasing RDP concentration), but for multiparous cows, BCS increased as RDP increased in the diet $(2.74,2.82,2.85$, and 2.89 for cows fed diets increasing in RDP concentration). It is not clear why BCS would decline for primiparous, but not for multiparous cows as RDP increases in the diet.

Maximizing synthesis of microbial protein as a relatively inexpensive source of readily digestible protein in the small intestine is desirable; however, inefficiency of protein use within the animal increases as RDP increases, causing concern of increased $\mathrm{N}$ excreted as waste. In this experiment, $\mathrm{N}$ efficiency declined from 36.5 to $28.2 \%$ as RDP increased from 6.8 to $11.0 \%$ of DM (Table 6; Figure 2). Within the treatment in which cows were fed the lowest RDP diet, $\mathrm{N}$ efficiency decreased as CP intake increased $(P<0.001)$; however, this response within treatment was not observed $(P>$ 0.10 ) when cows were fed the diets with higher concentrations of RDP. The high efficiency of $\mathrm{N}$ use for the low RDP diets must be largely attributed to the highly efficient use of RUP in the base diet. As RDP was added to the diet, with only $19 \%$ efficiency of use for milk 


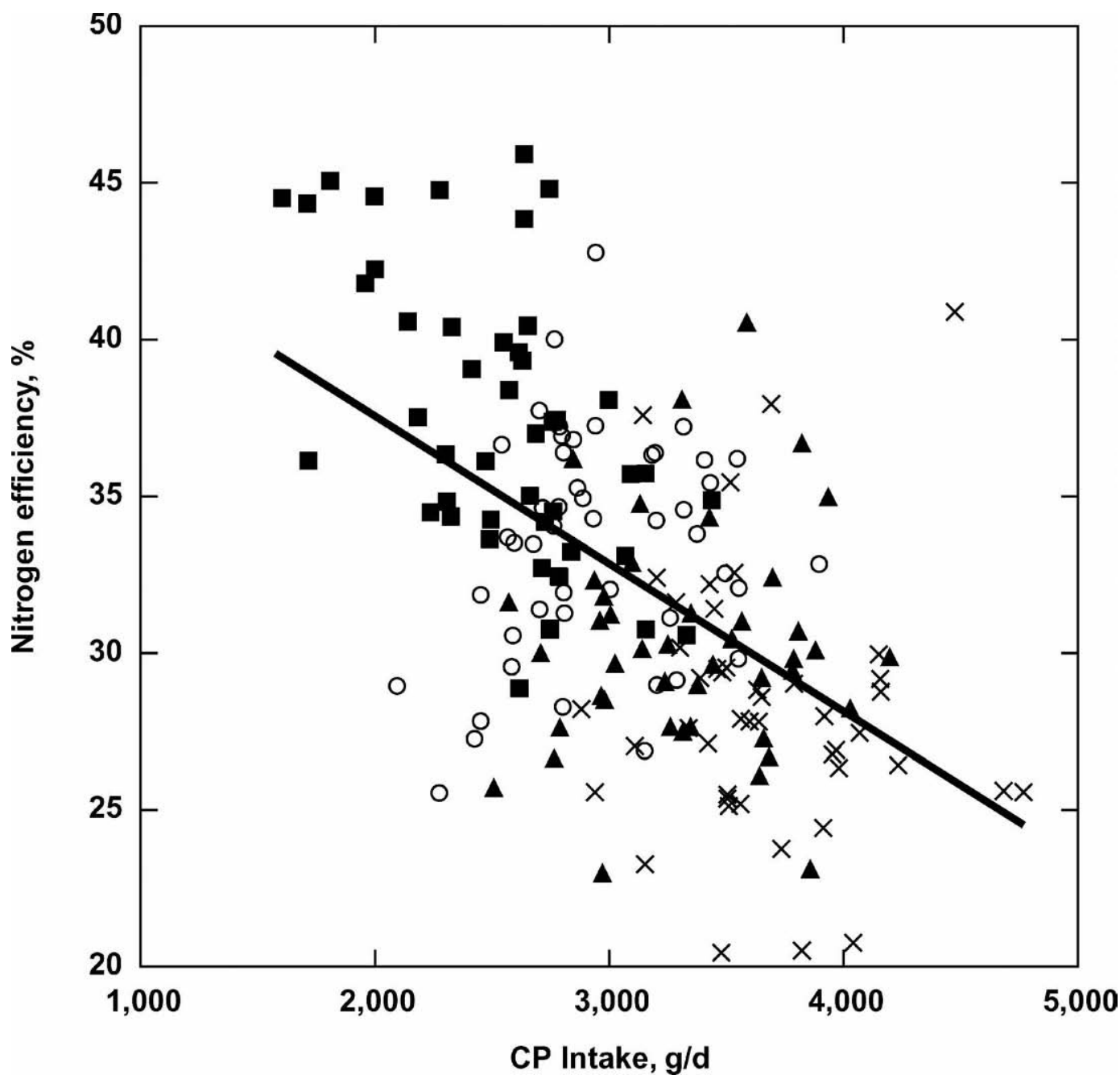

Figure 2. Effect of RDP intake (g/d) on efficiency of conversion of feed $\mathrm{N}$ to milk $\mathrm{N}(\%)$ for cows fed diet RDP concentrations of 6.8 ( $\square$ ), $8.2(\mathrm{O}), 9.6(\mathbf{\Delta})$, and $11.0(\times) \%$ of DM. The equation is $\mathrm{Y}\left(\mathrm{N}\right.$ efficiency, \%) $=47(\mathrm{SE}=1.8)-4.8(\mathrm{SE}=0.56) \times(\mathrm{CP}, \mathrm{kg} / \mathrm{d})$ with $\mathrm{R}^{2}=0.28$.

protein, the efficiency of CP use was diluted even as milk protein increased.

In this study, MUN increased linearly from $9.5 \mathrm{mg} /$ $\mathrm{dL}$ for cows fed the lowest RDP diet to $16.4 \mathrm{mg} / \mathrm{dL}$ for cows fed the highest RDP diet $(P<0.001)$. Milk urea $\mathrm{N}$ concentration reflects the urinary $\mathrm{N}$ excretion rate (Jonker et al., 1998; Kohn et al., 2002). Because the experiment was conducted before changes in MUN standards (Kohn et al., 2002), the model of Jonker et al. (1998) was used to estimate urinary $\mathrm{N}$ excretion for this experiment $($ mean bias $=0.05 \mathrm{mg} / \mathrm{dL} ; \mathrm{RMSPE}=$ $4.24 \mathrm{mg} / \mathrm{dL}$ ). Assuming that protein retention is negligible compared with protein used for milk production, $\mathrm{N}$ excretion in urine and feces can be calculated as shown in Table 6. In agreement with Kalscheur et al. (2000) and Hristov et al. (2004), predicted urinary $\mathrm{N}$ excretion increased linearly as RDP increased in the diet. In dis- agreement with Kalscheur et al. (2000) and Hristov et al. (2004), predicted fecal $\mathrm{N}$ estimate, which includes retained $\mathrm{N}$, increased significantly as RDP increased in the diet. Most total collection experiments (Dinn et al., 1998; Kalscheur et al., 2000) show protein retention increases with protein concentration in the diet. However, this increase may be a result of measurement error rather than true retention (Spanghero and Kowalski, 1997). If $\mathrm{N}$ retention increased from 25 to $45 \mathrm{~g} / \mathrm{d}$ as RDP increased as indicated by Kalscheur et al. (2000) using similar diets, then fecal $\mathrm{N}$ would be similar across treatments consistent with Kalscheur et al. (2000).

To accurately formulate diets for dairy cattle, the requirements for the expected level of milk production need to be balanced against the expected supply of nutrients from the feeds available. Predicting DMI is a critical component to predicting supply of nutrients. 
Although DMI can be measured for groups of cows on a farm, diet formulation requires knowledge of the DMI of individual cows when they are fed the new diet. Therefore, accurate DMI predictions are essential for accurate diet formulation. Figure 3 shows the individual cow DMI predicted by each model minus that observed in this study vs. the predicted DMI. The NRC 1989 model predicted an average of $1.0 \mathrm{~kg} / \mathrm{d}$ lower DMI than observed, whereas the 2001 model predicted an average of $1.2 \mathrm{~kg} / \mathrm{d}$ greater DMI than observed. Thus, the different predictions of DMI explain a part of the reason the NRC 1989 model formulated for a higher RUP content than the NRC 2001 model. The NRC 1989 estimates DMI as the amount needed to match energy requirements per day with the energy supplied by feeds: DMI $(\mathrm{kg} / \mathrm{d})=$ energy required per day/energy provided per kilogram of feed. When a feed of greater estimated energy content is offered, the DMI is expected to be lower. The NRC 2001 model estimates DMI using an empirical model that includes milk yield, BW, and DIM. This prediction is insensitive to energy content of the feed.

In addition to predicting DMI for an expected level of milk production, accurate diet formulation also requires predicting the amount of nutrients needed for milk production assuming a certain DMI. Allowable (predicted) milk is a term to define the amount of milk that can be produced from a diet consumed. In this case, where protein is the limiting nutrient, it is the amount of milk supported by the level of available protein. The predicted milk yield - observed vs. observed milk yield - control (high RDP) milk is shown in Figure 4. Negative values on the $\mathrm{x}$-axis represent losses in milk production compared with that expected for that cow and period if fed the 11\% RDP diet. The actual milk production and DMI were used to predict allowable milk for both NRC models (1989 and 2001). A perfect model would accurately predict milk yield when protein is limiting production ( 0 on the $y$-axis when values on the $\mathrm{x}$-axis are negative), and predict equal or greater milk yield than observed when protein may not be limiting milk production (positive values on the y-axis when values on the $\mathrm{x}$-axis are positive). For the 2 dietary treatments with the greatest losses in milk production (6.8 and 8.2\% RDP), both NRC models (1989 and 2001) overestimated milk production loss to a similar extent. However, the NRC 2001 model failed to predict that a loss would occur on the $9.6 \%$ RDP diet, and the 1989 model predicted the slight loss accurately. The NRC 2001 model also predicted greater DMI than the 1989 model so that assuming predicted DMI would have further supported the apparently incorrect assumption that the 9.6\% RDP diet was adequate (Table 4).
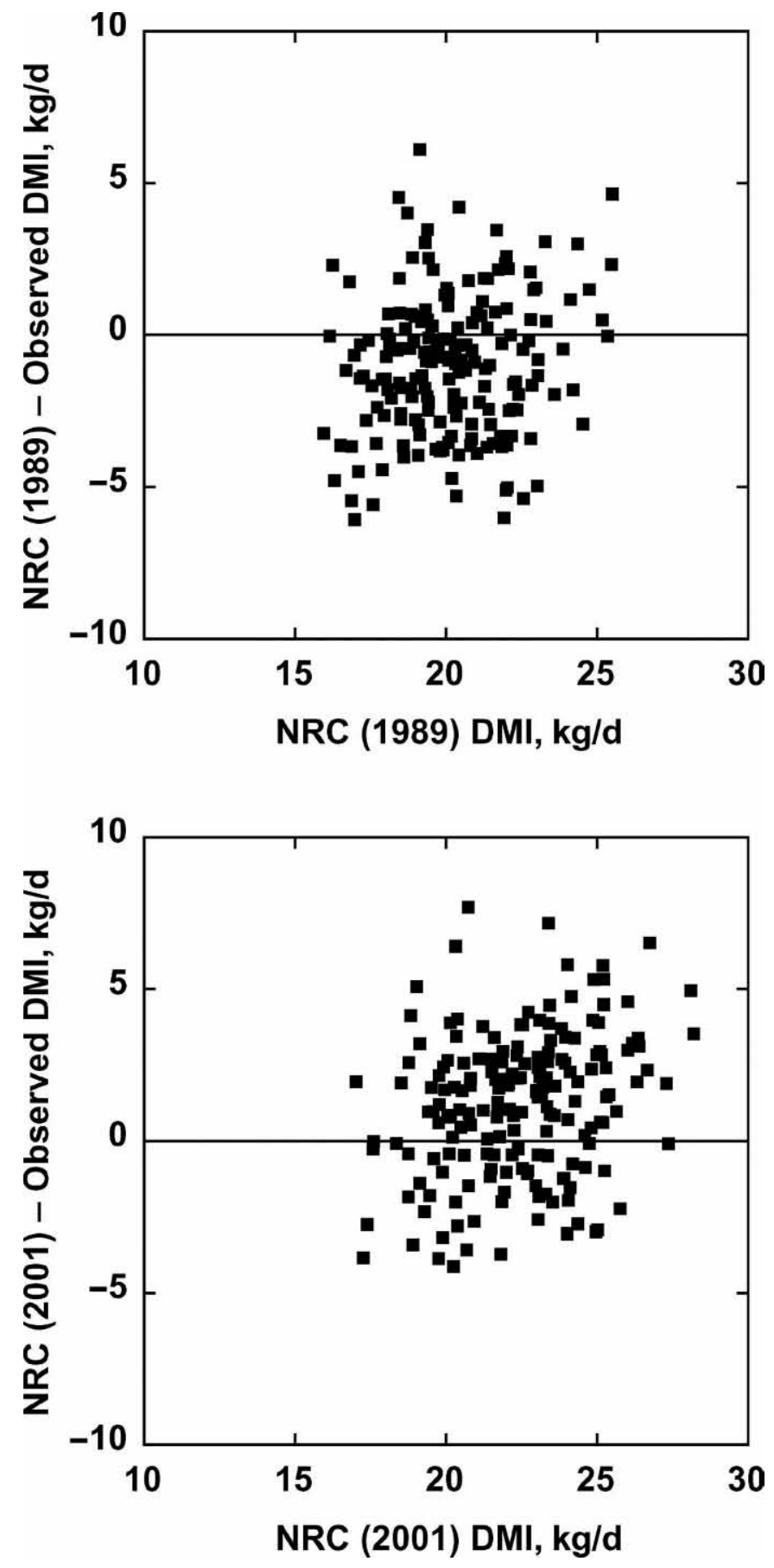

Figure 3. Predicted (NRC 1989 or 2001) minus observed DMI vs. predicted DMI. Predictions assumed actual milk yield and feed composition as analyzed. NRC, 1989: mean bias (predicted - observed $)=-1.01 \mathrm{~kg} / \mathrm{d}$, root mean square prediction error $(\mathrm{RMSPE})=$ $2.73 ;$ NRC, 2001: mean bias $=1.20 \mathrm{~kg} / \mathrm{d}, \mathrm{RMSPE}=2.66$.

The main purpose of the NRC models is to predict how much RDP is needed to avoid a loss in milk yield. The NRC 1989 model best met that challenge with the most accurate DMI prediction, and prediction of the 

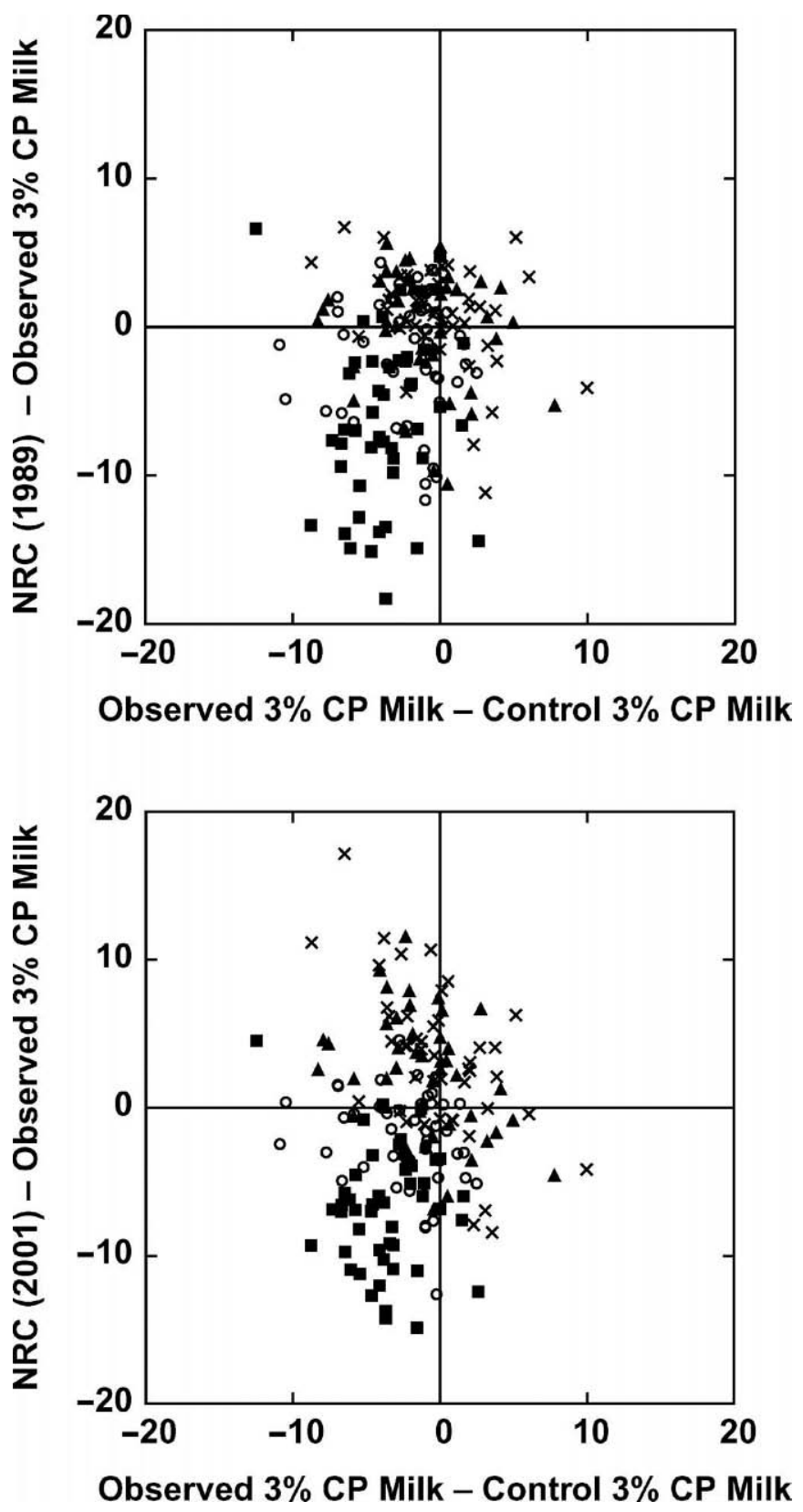

Figure 4. Predicted (NRC 1989 or 2001) minus observed milk yield (corrected for $3 \% \mathrm{CP}$ ) vs. observed minus control milk yield (corrected for $3 \% \mathrm{CP}$ ). Control milk was that observed with 11\% RDP diet (DM basis) corrected for period and cow effects. Models used observed DMI and feed composition. The NRC 1989 model was modified by reversing coefficients to estimate RDP required from microbial $\mathrm{CP}$ to estimate microbial CP from limited RDP. The RDP concentrations $(\mathrm{g} / 100 \mathrm{~g}$ of $\mathrm{DM})$ were $6.8(\mathbf{\square}), 8.2(\mathrm{O}), 9.6(\mathbf{\Delta})$, and $11.0(\times) \%$ of DM. NRC, 1989: mean bias $=-1.94 \mathrm{~kg} / \mathrm{d}$, root mean square prediction error $(\mathrm{RMSPE})=5.50$; NRC, 2001 : mean bias $=-1.04 \mathrm{~kg} / \mathrm{d}$, RMSPE $=5.98$

RDP level at which milk protein losses would occur. Both models overpredicted the degree of losses due to inadequate RDP. This would have made both models inappropriate to optimize protein requirements to re- duce environmental nitrogen losses because they overestimated the magnitude of potential losses in milk production.

To optimally formulate diets for dairy cows, the risks to the environment from overfeeding $\mathrm{N}$ need to be balanced against the risks of lost milk production from underfeeding. The results from the present study help quantify the effects of underfeeding RDP on milk production and urinary $\mathrm{N}$ excretion. In this study, RDP was increased by replacing 5\% of the diet DM supplied as corn grain and protected soybean meal with regular soybean meal. The DMI did not change and averaged 21 $\mathrm{kg} / \mathrm{d}$. Thus, $0.7 \mathrm{~kg} / \mathrm{d}$ corn grain and $0.47 \mathrm{~kg} / \mathrm{d}$ protected soybean meal ( 3 or $2 \%$ substitution $\times 21 \mathrm{~kg} / \mathrm{d} / 90 \% \mathrm{DM}$ ) were replaced with $1.17 \mathrm{~kg}$ of regular soybean meal between each treatment. The cost of this substitution would be $\$ 0.072 / \mathrm{d}$ per cow $(1.17 \times \$ 0.220-0.7 \times$ $\$ 0.097-0.47 \times \$ 0.25)$. The average change in milk yield between treatments was $0.7 \mathrm{~kg} / \mathrm{d}$, average change in milk fat was $43.3 \mathrm{~g} / \mathrm{d}$, and change in milk protein was $36.7 \mathrm{~g} / \mathrm{d}$. Thus, the average change in value of milk between treatments was: $\$ 0.32 / \mathrm{d}$ per cow $(\$ 3.33 / \mathrm{kg} \times$ $0.0433 \mathrm{~kg}$ fat $/ \mathrm{d}$ per cow $+\$ 4.68 / \mathrm{kg} \times 0.0367 \mathrm{~kg}$ of protein $/$ $\mathrm{d}$ per cow $+\$ 0.15 \times 0.7 \mathrm{~kg}$ of milk $/ \mathrm{d}$ per cow $\times 0.057 \mathrm{~kg}$ of other solids/kg of milk). Feeding below RDP requirement by substituting corn and protected soybean meal for regular soybean meal resulted in 4.4 times greater loss in milk income as would have been saved in feed cost.

The loss in milk production currently far outweighs the benefits of reduced $\mathrm{N}$ excretion. However, further research into balancing rations for groups of cows may find it acceptable to risk some loss in milk production of the cows with the greatest requirements to reduce $\mathrm{N}$ excretion of an entire group. To proceed with developing models to balance risks and benefits of protein feeding levels, particularly for groups of animals, the losses from underfeeding CP need to be quantified.

This study demonstrates that even when feeding below $\mathrm{CP}$ requirements, as dietary $\mathrm{CP}$ increases, the efficiency of $\mathrm{N}$ use declines and the amount of urinary $\mathrm{N}$ losses increases. Thus, diets formulated for maximal milk production may not be optimal to minimize $\mathrm{N}$ excretion per unit of milk produced.

\section{CONCLUSIONS}

Cows fed diets formulated to be below NRC requirements for RDP had reduced milk production, milk fat, and milk protein indicative of inadequate dietary RDP for rumen microbial growth. As RDP was increased in the diet of lactating dairy cows, MUN concentrations increased linearly and the efficiency of conversion of feed $\mathrm{N}$ to milk $\mathrm{N}$ decreased. 


\section{REFERENCES}

Allen, M. S. 1999. Effects of diet on short-term regulation of feed intake by lactating dairy cows. J. Dairy Sci. 83:1598-1624.

AOAC. 1990. Official Methods of Analysis. 15th ed. Association of Official Analytical Chemists, Arlington, VA.

Armentano, L. E., S. J. Bertics, and J. Riesterer. 1993. Lack of response to addition of degradable protein to a low protein diet fed to midlactation dairy cows. J. Dairy Sci. 76:3755-3762.

Bibby, J., and H. Toutenburg. 1977. Pages 16-19 in Prediction and Improved Estimation in Linear Models. John Wiley \& Sons, London, UK.

Capitol Commodity Services, Inc. 2005. Online. Available at: www.ccstrade.com/quotes/historical/ Accessed July 8, 2005.

Clark, J. H., T. H. Klusmeyer, and M. R. Cameron. 1992. Microbial protein synthesis and flows of nitrogen fractions to the duodenum of dairy cows. J. Dairy Sci. 75:2304-2323.

Dinn, N. E., J. A. Shelford, and L. J. Fisher. 1998. Use of the Cornell Net Carbohydrate and Protein System and rumen-protected lysine and methionine to reduce nitrogen excretion from lactating dairy cows. J. Dairy Sci. 81:229-237.

Erdman, R. A., J. H. Vandersall, E. Russek-Cohen, and G. Switalski. 1987. Simultaneous measures of rates of ruminal digestion and passage of feeds for prediction of ruminal nitrogen and dry matter digestion in lactating dairy cows. J. Anim. Sci. 64:565-577.

Faverdin, P. 1999. The effect of nutrients on feed intake in ruminants. Proc. Nutr. Soc. 58:523-531.

Gill, J. L. 1978. Design and Analysis of Experiments in the Animal and Medical Sciences; Vol. I. Iowa State University Press, Ames.

Hristov, A. N., R. P. Etter, J. K. Ropp, and K. L. Grandeen. 2004. Effect of dietary crude protein level and degradability on ruminal fermentation and nitrogen utilization in lactating dairy cows. J. Anim. Sci. 82:3219-3229.

Jonker, J. S., R. A. Kohn, and R. A. Erdman. 1998. Using milk urea nitrogen to predict nitrogen excretion and utilization efficiency in lactating dairy cows. J. Dairy Sci. 81:2681-2692.

Kalscheur, K. F., B. P. Glenn, R. L. Baldwin, and R. A. Kohn. 2000. Effect of increasing ruminally degraded protein on ruminal and total tract digestion of nutrients of dairy cows. J. Dairy Sci. 83(Suppl. 1):297. (Abstr.)
Kohn, R. A., K. F. Kalscheur, and M. Hanigan. 1998. Evaluation of models for balancing the protein requirements of dairy cows. J. Dairy Sci. 81:3402-3414.

Kohn, R. A., K. F. Kalscheur, and E. Russek-Cohen. 2002. Evaluation of models to estimate urinary nitrogen and expected milk urea nitrogen. J. Dairy Sci. 85:227-233.

Licitra, G., T. M. Hernandez, and P. J. Van Soest. 1996. Standardization of procedures for nitrogen fractionation of ruminant feeds. Anim. Feed Sci. Technol. 57:347-358.

Mead, R., R. N. Curnow, and A. M. Hasted. 1993. Pages 76-79 in Statistical Methods in Agriculture and Experimental Biology. 2nd ed. Chapman and Hall, London, UK.

Mertens, D. R. 2002. Gravimetric determination of amylase-treated neutral detergent fiber in feeds with refluxing in beakers or crucibles: Collaborative study. J. AOAC 85:1217-1240.

M'hamed, D., P. Faverdin, and R. Verite. 2001. Effects of the level and source of dietary protein on intake and milk yield in dairy cows. Anim. Res. 50:205-211.

National Research Council. 1989. Nutrient Requirements of Dairy Cattle. 6th rev. ed. Natl. Acad. Sci., Washington, DC.

National Research Council. 2001. Nutrient Requirements of Dairy Cattle. 7th rev. ed. Natl. Acad. Sci. Washington, DC.

SAS Institute. 1996. SAS/STAT Software: Changes and Enhancements through Release 6.11. SAS Inst., Inc., Cary, NC.

Spanghero, M., and Z. M. Kowalski. 1997. Critical analysis of N balance experiments with lactating cows. Livest. Prod. Sci. 52:113-122.

Stokes, S. R., W. H. Hoover, T. K. Miller, and R. Blauweikel. 1991a. Ruminal digestion and microbial utilization of diets varying in type of carbohydrate and protein. J. Dairy Sci. 74:871-881.

Stokes, S. R., W. H. Hoover, T. K. Miller, and R. P. Manski. 1991b. Impact of carbohydrate and protein levels on bacterial metabolism in continuous culture. J. Dairy Sci. 74:860-870.

Wohlt, J. E., and J. H. Clark. 1978. Nutritional value of urea versus preformed protein for ruminants. I. Lactation of dairy cows fed corn based diets containing supplemental nitrogen from urea and/ or soybean meal. J. Dairy Sci. 61:902-915.

USDA. 2005. Milk Marketing Order Statistics, Agricultural Marketing Service, USDA. http://www.ams.usda.gov/dyfmos/mib/ nass_fedord_prc.htm Accessed July 8, 2005. 